\title{
MAKNA TENUN IKAT DAYAK SINTANG DITINJAU DARI TEORI SEMIOTIKA SOSIAL THEO VAN LEEUWEN
}

\author{
Meaning of Ikat Dayak Sintang Weaving from The Theory of Social \\ Semiotics Theo Van Leeuwen
}

\author{
Januarti $^{1)}$, Jefri Audi Wempi ${ }^{2)}$ \\ 1) Marketing Communication, STIKOM LSPR - Jakarta \\ ${ }^{2)}$ Dosen Ilmu Komunikasi, STIKOM LSPR - Jakarta
}

\begin{abstract}
Sintang's Dayak ikat weaving, which is one of the cultural artifacts of Sintang District, West Kalimantan, is used by indigenous peoples (Dayak tribes) as part of their lives in the process of weaving and local customary events. In addition, Sintang's Dayak ikat weaving is also used as a local branding communication medium through its use in the formal and informal activities of the government and the private sector, for example, in welcoming guests and giving souvenirs. However, the tradition of Sintang's Dayak ikat weaving was once abandoned by the Dayak people because it was considered a symbol of underdevelopment or backwardness. Through the collaboration of several non-governmental institutions, a revitalization of Dayak ikat weaving was carried out which caused a shift in the meaning of Sintang's Dayak ikat weaving. This matter forms the basis for the present research into the meaning of Sintang's Dayak ikat weaving which uses Theo Van Leeuwen's semiotic social theory to understand: the meaning of Sintang's Dayak ikat weaving, interpretation by the sign readers of Sintang's Dayak ikat weaving, and how signs and meanings are exchanged based on semiotic resources. This is a qualitative study using the interpretive paradigm. Data collection was carried out through unstructured interviews with people who come in direct contact with the weaving process and people who enjoy woven products, as well as field observations and literature studies. The results showed that the meaning of Sintang's Dayak ikat weaving went through a shift when there were influences from outside that changed the views of the Dayaks regarding Sintang's Dayak ikat weaving, and its meaning is formed today by its function as cultural artifacts, regional identities, economic commodities and tourism potential and investment.
\end{abstract}

Keywords; social semiotics, ikat weaving, culture, sintang

\begin{abstract}
ABSTRAK
Tenun ikat Dayak Sintang yang merupakan salah satu artefak budaya di Kabupaten Sintang, Kalimantan Barat digunakan oleh masyarakat adat (suku Dayak) sebagai bagian dari kehidupan mereka dalam proses penenunan dan acara adat istiadat setempat. Selain itu, tenun ikat Dayak Sintang juga digunakan sebagai media komunikasi identitas daerah Sintang (local branding) melalui penggunaannya dalam kegiatan formal dan non formal pemerintah dan pihak swasta, misalnya dalam penyambutan tamu dan pemberian cendera mata. Namun, tradisi menenun tenun ikat Dayak Sintang pernah ditinggalkan oleh masyarakat Dayak karena tenun ikat Dayak Sintang dianggap sebagai lambang ketertinggalan atau keterbelakangan. Melalui kerja sama beberapa lembaga non pemerintah dilakukan revitalisasi tenun ikat Dayak yang membuat makna tenun ikat Dayak Sintang mengalami pergeseran. Hal tersebut mendasari peneliti melakukan penelitian mengenai makna tenun ikat Dayak Sintang ditinjau dari teori semiotika sosial Theo Van Leeuwen untuk memahami: makna dari tenun ikat Dayak Sintang, interpretasi pembaca tanda atas tenun ikat Dayak Sintang, dan bagaimana tanda dan makna dipertukarkan berdasarkan semiotic resources. Penelitian ini adalah penelitiaan kualitatif dengan menggunakan paradigma interpretif. Teknik pengumpulan data dilakukan dengan wawancara tidak terstruktur pada orang-orang yang bersentuhan langsung dengan proses penenunan dan orang-orang yang menikmati hasil tenunan, serta observasi lapangan dan studi literatur. Hasil penelitian menunjukkan bahwa makna tenun ikat Dayak Sintang mengalami pergeseran ketika ada pengaruh dari luar yang mengubah pandangan orang Dayak mengenai tenun ikat Dayak Sintang, dan saat ini makna yang terbentuk adalah sebagai artefak budaya, identitas daerah, komoditas ekonomi serta potensi wisata dan investasi.
\end{abstract}

Kata Kunci; semiotika sosial, tenun ikat, budaya, sintang 


\section{PENDAHULUAN}

Tenun ikat Dayak Sintang yang merupakan salah satu artefak budaya suku Dayak di Kabupaten Sintang dahulu digunakan para leluhur suku Dayak untuk menyampaikan pesan, nasihat dan kebudayaan suku Dayak kepada anak cucu mereka melalui motif dan cerita motif di dalamnya (Maessen, wawancara, Tgl 29 Agustus, 2018). Tenun ikat tersebut juga dipakai untuk pakaian sehari-hari dan kegiatan adat istiadat seperti adat memandikan anak ke sungai, pernikahan, kematian, menyambut kepala hasil ngayau (head hunting), mengambil semengat (roh) padi, menumbuk padi, gawai tutup tahun atau panen dan sebagainya (Entulan \& Tawai, wawancara, Tgl 26 Agustus, 2018).

Menurut Maessen dan Sembai (wawancara, Tgl $29 \& 31$ Agustus, 2018) pada saat masyarakat Dayak sudah mulai mengenal pakaian jadi seperti $t$-shirt, masyarakat tidak lagi mau menggunakan tenun ikat karena mereka akan dipandang primitif, kampungan, dan tidak punya pendidikan oleh orang-orang di kampungnya. Ketidakinginan tersebut juga diterapkan anak-anak yang sudah bersekolah ke kota (SMP). Alhasil, tradisi menenun mulai ditinggalkan oleh masyarakat.

Bertahun-tahun kemudian, inisiatif untuk melestarikan kembali tradisi menenun dimulai melalui seorang biarawan asal Belanda bernama pastor Jacques Maessen, SMM. Ia adalah seorang imam dari kongregasi Serikat Maria Montfortan (SMM) yang sangat peduli terhadap seni dan budaya. Hal yang ia lakukan adalah menyediakan bahan baku untuk menenun dan kacamata bagi ibu-ibu penenun yang berusia lanjut. Barulah pada tahun 1999 diadakan kerja sama dengan beberapa lembaga non pemerintah (Yayasan KOBUS [Komunikasi Budaya dan Seni] - PRCF [People, Resources, and Conservation Foundation]/PRCF Indonesia - YSDK [Yayasan Swadaya Dian Khatulistiwa], atas dukungan Ford Foundation) untuk memaksimalkan proses pelestarian tradisi menenun sekaligus membantu masyarakat untuk mendapatkan penghasilan tambahan bagi keluarga.

\footnotetext{
*Korespondensi Penulis:

E-mail: angelajanuartikwee87@gmail.com
}

Program ini dikenal dengan nama "Restorasi Tenun Ikat Dayak". Beberapa tahapan dilakukan dalam Restorasi Tenun Ikat Dayak ini seperti memetakan jumlah penenun, sebaran penenun, tingkat keahlian penenun, produktivitas penenun dan pemasaran kain hasil tenunan. Setahun berikutnya, masyarakat bersepakat untuk berhimpun dalam kelompok yang dinamakan Kelompok Usaha Bersama Jasa Menenun Mandiri (KUBJMM) yang pada tahun 2001 diubah menjadi berbadan hukum Koperasi [Koperasi JMM]. Pada awal Restorasi Tenun Ikat Dayak, jumlah penenun tercatat hanya 40-an orang yang tersebar di lima dusun atau desa seperti Baning Panjang, Ensaid Panjang, Ransi Panjang, Menaung dan Umin. Namun, dari jumlah tersebut hanya sekitar belasan orang yang benar-benar ahli menenun dan usia mereka sudah di atas 45 tahun (PRCF Indonesia, 2008). Jumlah tersebut meningkat dengan signifikan menjadi 321 orang penenun (anggota koperasi) yang tersebar di 13 dusun dan desa (data koperasi JMM per Desember 2017).

Berkat kerja sama dari berbagai pihak, tenun ikat Dayak Sintang telah dikenal masyarakat luas mulai dari lokal, nasional dan internasional. Bahkan, pada tahun 2015 tenun ikat Dayak Sintang telah terdaftar sebagai Warisan Budaya Tak Benda (WBTB) Indonesia yang dikelola oleh Direktorat Jenderal Kebudayaan, Kementerian Pendidikan dan Kebudayaan, dalam kategori Kemahiran dan Kerajinan Tradisional ("Kemdikbud," n.d.). Namun, bagaimana orang-orang yang menenun, membeli, mengoleksi dan memakai tenun ikat Dayak Sintang memaknai tenun ikat tersebut menjadi hal yang menarik untuk diteliti. Terkait dengan pemaknaan, penulis membaginya menjadi :

1. Makna bagi orang-orang yang berada di dekat proses penenunan seperti pengurus adat, temenggung, penenun, orang yang terlibat dalam revitalisasi, karyawan koperasi JMM dan penjual tenun ikat Dayak Sintang.

2. Makna bagi orang yang menikmati hasil (kolektor dan pemakai). 
Makna-makna yang muncul dari para narasumber akan diteliti menggunakan teori semiotika sosial Theo Van Leeuwen, sehingga nanti akan dipahami makna dari objek penelitian, interpretasi pembaca tanda atas

\section{Kerangka Teoritis}

Semiotika Sosial dalam bahasa Yunani disebut 'Semeion' yang berarti tanda (sign). Salah satu definisi semiotika yang paling terkenal adalah dari Ferdinand de Saussure (1974 [1916]: 16) 'A science that studies the life of signs within society is conceivable...I shall call it semiology' (Leeuwen, 2005, p. 3). Semiotika sosial adalah studi tentang produksi, penggunaan, dan interpretasi sumber tanda (artefak dan tindakan) dalam kehidupan sosial. Semiotika sosial berfokus pada bagaimana masyarakat menggunakan semiotics 'resources' dalam memproduksi atau menginterpretasi artefak dan kegiatan komunikatif (Wempi, 2018).

Leeuwen (2005) dalam bukunya Introducing Social Semiotics menuturkan istilah 'sumber daya semiotika' (semiotic resources) adalah istilah kunci dalam semiotika sosial. Ini berasal dari karya Halliday yang berpendapat bahwa tata bahasa bukan sebuah kode, bukan seperangkat aturan untuk menghasilkan kalimat yang benar, tetapi 'sumber daya untuk membuat makna' (1978: 192). Kemudian Leeuwen mengembangkan ide tersebut dalam 'tata bahasa' mode semiotika yang lain dan mendefinisikan sumber daya semiotika sebagai tindakan dan artefak yang digunakan untuk berkomunikasi, apakah mereka diproduksi secara fisiologis - dengan alat vokal kita; dengan otot yang kita gunakan untuk membuat ekspresi wajah dan gerak tubuh, dll - atau dengan sarana teknologi dengan pena, tinta dan kertas; dengan perangkat keras dan perangkat lunak komputer; dengan kain, gunting dan mesin jahit, dll (Leeuwen, 2005, p. 3).

Terdapat dimensi-dimensi pokok dalam analisis semiotika sosial Leeuwen (2005), yakni discourse, genre, style, dan modality. Leeuwen menjelaskan konsep discourse (wacana) sebagai kunci untuk mempelajari bagaimana sumber daya semiotika digunakan untuk membangun representasi dari apa yang sedang terjadi di dunia. Konsep genre adalah kunci objek penelitian, dan bagaimana tanda dan makna dipertukarkan berdasarkan semiotic resources.

untuk mempelajari bagaimana sumber daya semiotika digunakan untuk memerankan interaksi komunikatif - interaksi yang melibatkan representasi - apakah tatap muka, seperti dalam percakapan, atau pada pemindahan waktu dan/atau tempat, seperti misalnya melalui sarana buku dan media lainnya. Konsep style (gaya) adalah kunci untuk mempelajari bagaimana orang menggunakan sumber daya semiotika untuk 'menunjukkan' genre, dan untuk mengekspresikan identitas dan nilai-nilai mereka dalam melakukannya. Sedangkan konsep modality (modalitas) adalah kunci untuk mempelajari bagaimana orang menggunakan sumber daya semiotika untuk menciptakan nilai-nilai kebenaran atau realitas dari representasi mereka, untuk berkomunikasi, misalnya, apakah mereka akan diambil sebagai fakta atau fiksi, kebenaran atau dugaan yang terbukti, dll (Leeuwen, 2005, p.91)

Proses yang terjadi dalam model teori di atas adalah tenun ikat Dayak Sintang sebagai objek mengirimkan tanda (Sign) kepada pembaca tanda (Sign Reader) yang terdiri dari pengurus adat, temenggung, penenun, orang yang terlibat dalam revitalisasi, karyawan koperasi JMM, penjual, kolektor dan pemakai kain tenun ikat Dayak Sintang, yang masingmasing memiliki sumber daya semiotika (Semiotic Resources).

Sumber daya semiotika yang berbedabeda dari pembaca tanda ini menghasilkan interpretasi yang berbeda-beda pula terhadap tanda yang dikirim oleh objek tersebut, sehingga pemaknaan yang muncul juga berbeda. Hasil pemaknaan dari interpretasi tanda tersebut kemudian dipertukarkan dari pembaca tanda yang satu kepada yang lain sehingga menimbulkan pembentukan makna yang baru. Rangkaian proses yang terjadi dalam lingkungan sosial tersebut akan dianalisis melalui empat sudut pandang yakni discourse, genre, style, dan modality. 


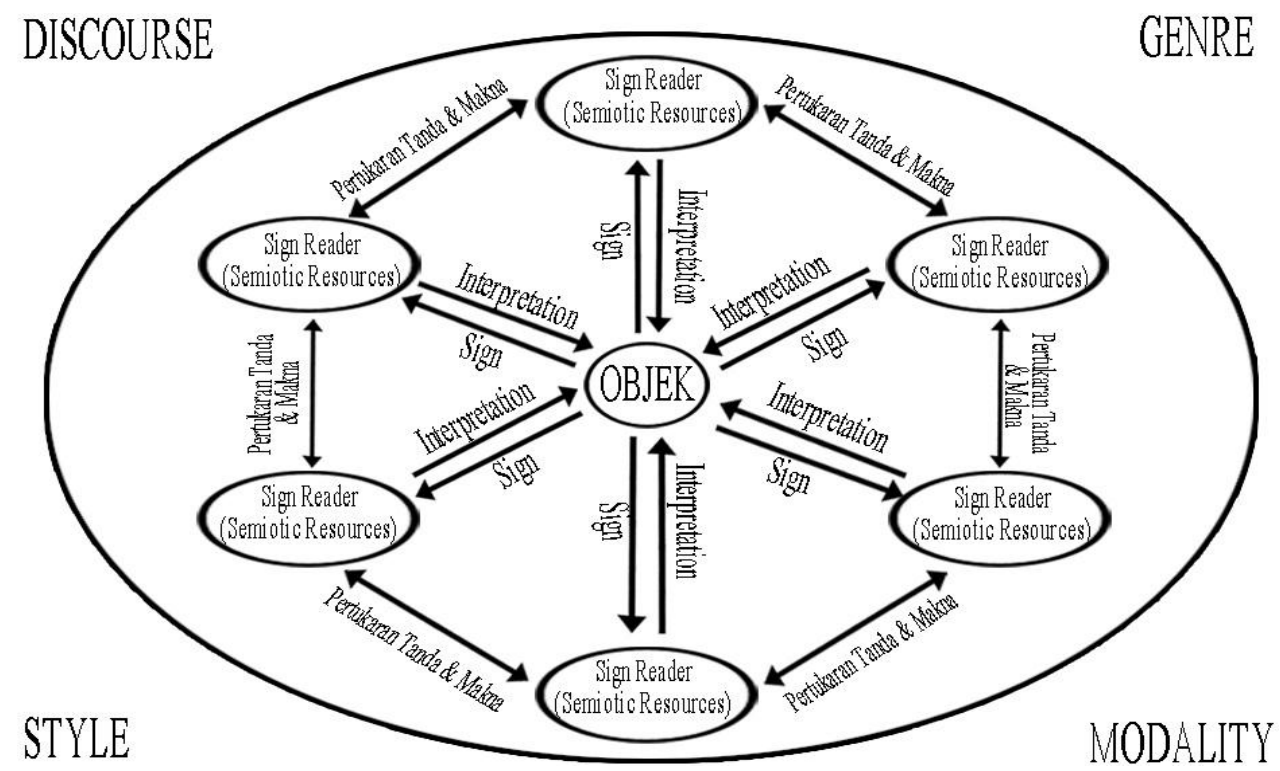

Gambar 1. Model Teori Semiotika Sosial Theo Van Leeuwen

Sumber : Olahan peneliti berdasarkan pemahaman atas buku Introducing Social Semiotics Theo Van Leeuwen (2005), 2018

\section{METODE PENELITIAN}

Penelitian ini menggunakan metode penelitian kualitatif. Creswell (2010) menyatakan "penelitian kualitatif merupakan metode-metode untuk mengekplorasi dan memahami makna yang - oleh sejumlah individu atau sekelompok orang - dianggap berasal dari masalah sosial atau kemanusiaan" (p. 4). Menurut Denzin \& Lincoln (2009), para peneliti kualitatif menekankan sifat realita yang terbangun secara sosial, hubungan erat antara peneliti dengan subjek yang diteliti, dan tekanan situasi yang membentuk penyelidikan. Para peneliti semacam ini mementingkan sifat penyelidikan yang sarat-nilai. Mereka mencari jawaban atas pertanyaan-pertanyaan yang menyoroti cara munculnya pengalaman sosial sekaligus perolehan maknanya (p. 6).

Teknik pengumpulan data dalam penelitian ini menggunakan data primer yang dilakukan dengan wawancara tidak terstruktur dan studi dokumen, dan data sekunder melalui observasi dan studi literatur. Narasumber untuk penelitian ini dibagi dalam dua kategori yakni :
1) Orang-orang yang berada di dekat proses penenunan:

a. Pengurus adat atau temenggung di Sintang, Ensaid Panjang, Ransi Panjang dan Umin,

b. Dua orang penenun di Ensaid Panjang, Umin, Ransi Pendek dan Ransi Panjang dengan rentangan usia 30-50 tahun dan >50-70 tahun,

c. Dua orang yang terlibat dalam revitalisasi tenun ikat Dayak Sintang,

d. Dua orang yang bekerja di koperasi JMM, e) Dua orang penjual kain tenun ikat Dayak Sintang.

2) Orang-orang yang menikmati hasil:

a. Dua orang dengan rentangan usia 2545 tahun,

b. Dua orang dengan rentangan usia $>45-$ 65 tahun.

Analisis data yang digunakan dalam penelitian ini disesuaikan dengan tiga tahapan yang dilakukan oleh peneliti semiotika seperti yang dikutip dari Introducing Social Semiotics (Leeuwen, 2005, p. 3), yaitu :

1. Mengumpulkan, mendokumentasikan, dan menyusun semiotic resource secara sistematis, termasuk catatan sejarahnya. 
2. Melakukan investigasi bagaimana resource tersebut digunakan pada sejarah tertentu, budaya dan konteks institusional, dan bagaimana masyarakat membicarakannya dalam konteks tersebut; merencanakannya, mengajarkannya, menilainya, dan mengkritiknya, dll.

3. Memberi kontribusi pada penemuan dan pengembangan semiotic resource baru dan cara penggunaan baru dari semiotic resource yang sudah ada.

Sedangkan teknik triangulasi data dilakukan dengan observasi mengenai kejadian dan perilaku narasumber selama penelitian di lapangan.

\section{HASIL DAN PEMBAHASAN}

\section{Deskripsi Objek Penelitian}

Tenun Ikat Dayak Sintang merupakan kain tenun ikat yang dihasilkan oleh penenunpenenun di Kabupaten Sintang, Kalimantan Barat. Nama tenun ikat Dayak Sintang dipakai untuk membedakan tenun ikat yang dimiliki Kabupaten Sintang dengan tenun ikat dari daerah lain di Indonesia. Selain itu, penggunaan kata 'Dayak' menjelaskan tentang suku yang membuat kain tenun ikat tersebut. Sedangkan kata 'Sintang' sebagai identitas daerah yang menghasilkan kain tenun ikat yakni Kabupaten Sintang. Penggunaan nama Tenun Ikat Dayak Sintang mulai dipakai pada tahun 2000 sejak dibentuknya Kelompok Usaha Bersama Jasa Menenun Mandiri (KUBJMM) (Sriyanti, Emiliana, \& Rosmawati, wawancara, Tgl 2 Februari, 2019).

Beberapa ciri khas yang ada di kain tenun ikat Dayak Sintang, misalnya, untuk kain dengan pewarna alam terdapat perbedaan warna di bagian ujung atas dan bawah kain, satu bagian berwarna kemerahan dan bagian lainnya kehitaman. Menurut Emiliana (wawancara, Tgl 25 Agustus, 2018) warna merah tersebut melambangkan siang dan hitam melambangkan malam, atau juga mencerminkan kehidupan manusia yang baik (merah) dan yang tidak baik (hitam). Ciri khas lainnya, setiap kain tenun ikat memiliki motif Seligi Beras, yang merupakan pinggiran kain atau benang penutup motif induk dan motif anak agar kain tampak lebih sempurna. Motif ini menyampaikan pesan bahwa kehidupan manusia belum sempurna jika belum terpenuhi kebutuhan akan beras yang menghasilkan nasi untuk dikonsumsi setiap saat sebagai makanan pokok (Yayasan Kobus, Koperasi Jasa Menenun Mandiri, \& Ford Foundation, 2011).

\section{Analisis Penelitian}

Analisis penelitian dijabarkan berdasarkan model teori semiotika sosial Theo Van Leeuwen sebagai berikut:

a) Tanda Pada Tenun Ikat Dayak Sintang

Bila melihat kain tenun ikat Dayak Sintang dalam wujud fisik, tanda-tanda yang dimunculkan terdiri dari motif kain, jenis kain, ukuran kain, pewarnaan kain dan bahan kain. Motif kain tenun ikat Dayak Sintang ini tergolong beragam dan umumnya dikategorikan dalam motif sakral dan motif tua (tuai). Motif sakral adalah motif-motif seperti motif Rabing (reptil) dan manusia yang hanya dapat dibuat oleh penenun berusia lanjut dan sudah memiliki pengalaman membuat banyak motif. Sedangkan motif tua merupakan motif-motif yang diajarkan sejak zaman nenek moyang seperti motif Merinjam dan Ruit.

Motif Merinjam pada kain tenun ikat Dayak Sintang mengingatkan orang Dayak pada ketiga raja tumbuhan yang memiliki kekuatan lebih dari semua jenis tumbuhan sejenis di bumi yakni Tebelian untuk raja dari semua jenis kayu, Uwi Segak untuk semua jenis tanaman Uwi (rotan) dan akar Tengang untuk semua jenis tanaman akarakaran. Motif Ruit (tombak) adalah motif kain yang memberi pesan bahwa dengan Ruit manusia dapat mengusahakan segala sesuatu untuk keberlangsungan hidupnya. Ruit melambangkan kekuatan ikatan hubungan antara laki-laki dan perempuan, Ruit juga memberi pesan dan tanggungjawab kepada kaum laki-laki yang dituntut untuk dapat bekerja keras di luar rumah mencari nafkah bagi keluarga (Yayasan Kobus, et al., 2011). Selain itu, 


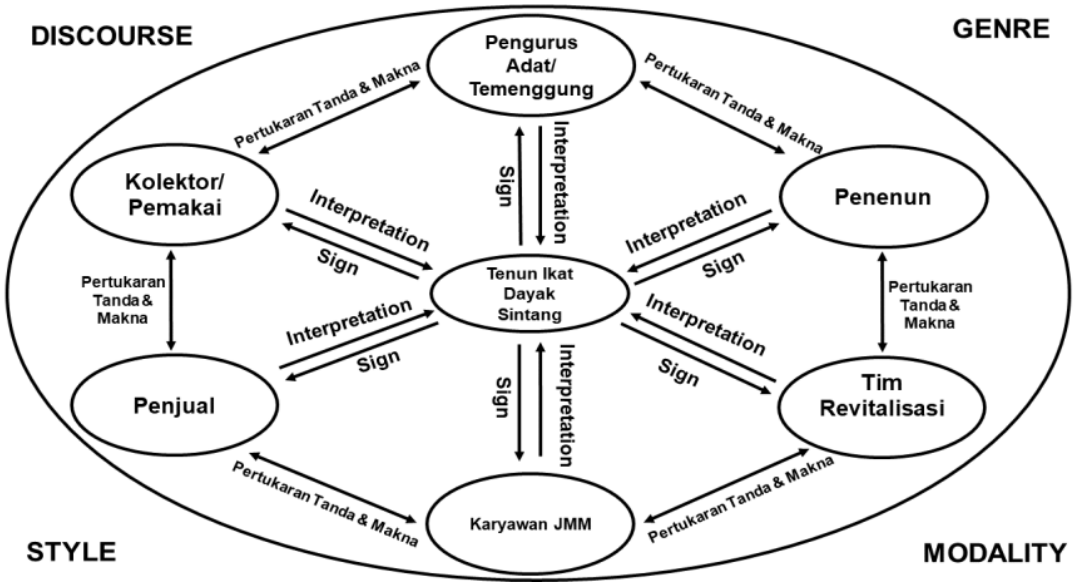

Gambar 2. Model Teori Semiotika Sosial Theo Van Leeuwen

Sumber : Olahan peneliti berdasarkan pemahaman atas buku Introducing Social Semiotics Theo Van Leeuwen (2005), 2018

ada pula motif tumbuh tumbuhan, ikan dan motif lain yang berkaitan erat dengan kehidupan orang Dayak diluar motif sakral dan tua yang dapat dibuat oleh para penenun.

Jenis kain tenun ikat Dayak Sintang yang umum dibuat oleh para penenun adalah pua/kumbu, kebat, selendang dan syal. Namun, jenis kain lain dapat dipesan sesuai dengan kebutuhan pembeli atau kolektor seperti jenis kain untuk sarung bantal, taplak meja, gelang tangan dan sebagainya. Selain itu, ukuran kain tenun ikat dapat beragam antara penenun yang satu dengan yang lain, hal ini dikarenakan tidak ada standar ukuran khusus untuk kain tenun ikat dan para penenun lebih fokus pada jenis kain. Ukuran kain untuk jenis kain pua/kumbu berkisaran $120 \mathrm{x}$ $202 \mathrm{~cm}, 114$ x $154 \mathrm{~cm}, 128$ x $196 \mathrm{~cm}, 129$ x $224 \mathrm{~cm}$, kain kebat berukuran 47 x 130 $\mathrm{cm}, 65 \times 131 \mathrm{~cm}, 128 \times 60 \mathrm{~cm}, 150 \times 52$ $\mathrm{cm}$, kain ukuran selendang $16 \times 160 \mathrm{~cm}$, $19,5 \times 145 \mathrm{~cm}, 13 \times 152 \mathrm{~cm}, 16 \times 212 \mathrm{~cm}$ dan ukuran syal $6,5 \times 136 \mathrm{~cm}, 6 \times 132 \mathrm{~cm}$, $7,5 \times 152 \mathrm{~cm}$ dan $6 \times 143 \mathrm{~cm}$.

Dalam pewarnaan kain tenun ikat Dayak Sintang, penenun menggunakan pewarna alam dari tumbuh-tumbuhan seperti akar mengkudu, daun tarum, daun kerebang, kulit pohon lengkar, daun kempait, dan sebagainya, serta pewarna kimia naptol. Sedangkan bahan untuk membuat kain tenun ikat berasal dari kapas yang ditanam sendiri oleh penenun dan benang yang dijual oleh pabrik.

b) Individu atau Sign Reader

Individu yang membaca tanda dari tenun ikat Dayak Sintang terdiri dari pengurus adat desa dan kabupaten, temenggung subsuku dan kabupaten, penenun di Desa Umin, Ensaid Panjang, Dusun Ransi Pendek dan Ransi Panjang, orang yang terlibat dalam revitalisasi, staf koperasi JMM, penjual, pemakai dan kolektor tenun ikat Dayak Sintang yang berada di Kota Sintang.

Pengurus adat yang berada di desa berasal dari Desa Umin, Ensaid Panjang, Dusun Ransi Pendek dan Ransi Panjang. Pengurus adat yang terpilih di dusun atau desa ditunjuk langsung oleh kepala desa sesuai Surat Keputusan (SK). Masa jabatannya adalah lima tahun dan dapat dipilih kembali. Tugasnya mengurus masalah hukum adat di dusun atau desa masing-masing (Bando, wawancara, $\mathrm{Tgl}$ 24 Agustus, 2018).

Para pengurus adat di Desa Umin dan Ensaid Panjang tergolong sangat baik dalam memahami tentang tenun ikat Dayak Sintang mulai dari sejarah hingga proses penenunan. Pengurus adat di Desa Umin mengatakan pengetahuan menenun diperoleh dari Inai Abang dan Dabong dari kayangan yang diajarkan kepada 
manusia pertama Kelimbung dan Lawa. Sedangkan, menurut pengurus adat di Desa Ensaid Panjang pengetahuan tersebut diperoleh dari binatang ingkat dan pewarnaan dari perbincangan burung ruai dan bubut yang didengar oleh manusia. Mereka juga dapat menjelaskan tentang proses penenunan seperti proses pengolahan bahan baku kapas dan bahan baku pewarnaan alam, nama dan cerita motif, serta pantangan dalam menenun. Selain itu, desa tempat mereka tinggal merupakan desa penghasil tenun ikat dan memiliki banyak penenun yang produktif. Sedangkan pengurus adat di dusun Ransi Pendek dan Ransi Panjang tidak memahami tentang tenun ikat Dayak Sintang dan ia hanya berfokus pada mengurus hukum adat. Dusun tempatnya bertugas juga menghasilkan tenun ikat Dayak Sintang namun jumlah penenunnya tidak terlalu banyak.

Sementara itu, pengurus adat di tingkat kabupaten adalah ketua Dewan Adat Dayak (DAD) Sintang. Ia dipilih oleh seluruh kecamatan di kabupaten dan dilantik berdasarkan Surat Keputusan DAD Provinsi (Oliv, 2017).. Tugas dari pengurus DAD ini adalah melestarikan adat budaya, memfasilitasi masyarakat dalam menyampaikan informasi atau permintaan kepada pemerintah, menjalin hubungan dengan pemerintah, dan sebagai sarana untuk berkumpul dan menyatukan persepsi masyarakat Dayak kabupaten, provinsi, dan seluruh Indonesia (Edward, komunikasi pribadi, September 3, 2018). Pengurus adat kabupaten ini mengaku tidak mengetahui secara persis sejarah mengenai tenun ikat dan hanya mengetahui bahwa tenun ikat sudah menjadi tradisi budaya masyarakat Dayak.

Selain itu, ada pula temenggung di Desa Umin dan temenggung subsuku sekaligus kabupaten Sintang. Berbeda dengan pengurus adat, seorang temenggung dipilih dan diangkat oleh masyarakat dan bersifat seumur hidup, kecuali ia tidak mampu lagi karena faktor kesehatan dan usia atau memiliki masalah. Seorang temenggung menguasai tentang hukum adat, hukum perdata dan perdana. Tugasnya berhubungan dengan seni, budaya dan adat istiadat. Dalam bertugas mengurus adat dan budaya, temenggung lebih tinggi dari kepala desa dan pengurus adat. Tingkatan temenggung dimulai dari temenggung suku, kecamatan, kabupaten dan provinsi. Temenggung suku, misalnya dapat memegang lebih dari satu kecamatan apabila suku tersebut berada di beberapa kecamatan (Bando, komunikasi pribadi, Agustus 24, 2018).

Temenggung di Desa Umin hanya mengetahui tentang tenun ikat yang berhubungan dengan adat, misalnya dahulu saat penduduk belum menganut agama, pernikahan diadakan secara adat, mempelai laki-laki dan perempuan diberi batas dengan kain tenun ikat, pengantin di selampai, dikipas-kipas dengan ayam, pengantin juga harus menggunakan pakaian dari kain tenun ikat dengan berbagai motif kecuali motif Rabing. Sedangkan temenggung suku sekaligus temenggung kabupaten sangat memahami tentang tenun ikat Dayak Sintang mulai dari subsuku yang dapat menenun, proses penenunan dan motif-motif pada kain tenun ikat.

Kemudian, para penenun yang tersebar di Desa Umin, Ensaid Panjang, Dusun Ransi Pendek dan Ransi Panjang secara umum belajar menenun sejak usia remaja, hanya dua orang yang benar-benar menekuni menenun setelah menikah dan punya anak. Pengetahuan mereka tentang sejarah menenun tidak terlalu mendalam, hanya satu yang mengatakan manusia belajar menenun dari binatang ingkat, sedangkan yang lain mengatakan mereka mendapatkan pengetahuan tersebut dari nenek moyang secara turun temurun. Keenam penenun ini juga memiliki fokus yang berbeda dalam menenun, ada yang fokus menenun dengan pewarna alam saja, ada yang pewarna alam dan kimia, ada pula yang hanya kimia saja. Mengenai motif pada kain tenun ikat, beberapa penenun mengaku tidak mengetahui cerita motif yang mereka buat karena ketika belajar mereka tidak bertanya kepada orangtua tentang cerita masing-masing motif.

Narasumber yang terlibat dalam revitalisasi tenun ikat Dayak Sintang 
terdiri dari perwakilan dari lembaga non pemerintah dan pemerintah, dan proses revitalisasi ini dilakukan di desa yang berbeda. Perwakilan dari lembaga non pemerintah lebih banyak berfokus pada memberikan pemahaman mengenai standarisasi produk seperti ukuran kain, belajar memintal benang, pewarnaan alam dan kimia, dan merubah mindset lama penenun.

Kemudian ada pula pendampingan beberapa penenun untuk studi banding ke Yogyakarta. Pengalaman selama pendampingan dalam revitalisasi ini membuat narasumber mulai memahami tentang tenun ikat Dayak Sintang, misalnya ia mendengar bahwa dahulu kain tenun ikat dipakai sebagai selimut untuk keperluan sehari-hari dan kadang untuk pernikahan, maka ada jenis kain bernama pua/kumbu yang berarti selimut. Menurutnya, keterampilan menenun diturunkan oleh orangtua kepada anakanak mereka, pengerjaan kain masih manual dan tidak menggunakan Alat Tenun Bukan Mesin (ATBM). Motif-motif kain tenun ikat seperti buaya dan manusia hanya dapat dibuat oleh orang tua (penenun berusia lanjut).

Berbeda dengan rekannya, narasumber perwakilan pemerintah lebih fokus memberikan pelatihan pembuatan kain tenun ikat dengan pewarnaan kimia. Para penenun diperkenalkan dengan pewarna naptol dan proses pencampuran warnanya, serta belajar membuat jenis kain syal dari kelebihan benang membuat jenis kain pua/kumbu dan kebat. Pengalaman dalam mendampingi para penenun membuat narasumber memahami menenun sebagai tradisi turun temurun dan tidak sembarangan (ada adatnya), terutama apabila membuat motif seperti buaya, penenun harus bertanya kepada yang lebih tua dan apabila ada orang yang meninggal di kampung tersebut untuk sementara mereka tidak boleh menenun.

Karyawan di koperasi JMM ada yang berlatar belakang penenun dan ada pula yang pernah terlibat langsung dalam program revitalisasi tenun ikat Dayak Sintang. Narasumber yang berlatar belakang penenun menceritakan keterampilan menenun diajarkan oleh orang-orang buah kana (Keling Kumang), karena zaman dahulu manusia dan orang buah kana yang setengah dewa hidup bersama-sama. Kain tenun ikat tersebut digunakan untuk pakaian karena mereka belum mengenai pakaian jadi. Menurutnya, motif tumbuh-tumbuhan bagus untuk usia pertama membuat kain tenun ikat sampai usia 50-an, sedangkan di atas 50-an dianggap sudah tua dan dapat membuat motif binatang, namun apabila belum berusia 60 -an tidak boleh membuat motif buaya, Rabing atau naga. Meski tidak mengikuti proses revitalisasi secara langsung, ia mendengar kisah tenun ikat Dayak Sintang mulai dikembangkan almarhum ibu Rinku bersama pastor Jacques Maessen, SMM pada tahun 1980an.

Narasumber yang memiliki pengalaman terlibat langsung proses revitalisasi menjelaskan program revitalisasi kerja sama lembaga non pemerintah dilakukan karena pastor Jacques Maessen, SMM yang sudah memulai revitalisasi kesulitan untuk mendampingi para pengrajin yang terdapat di banyak kampung di empat kecamatan yakni kecamatan Kelam Permai, Dedai, Sintang, dan Ketungau. Saat itu, pengrajin sudah banyak tetapi mereka tidak memiliki akses (jalan dan finansial) dari kampung ke Sintang atau sebaliknya. Program revitalisasi tersebut dimulai dengan mengidentifikasi pengrajin, identifikasi kebutuhan bahan, baik itu kapas dan bahan-bahan pewarna yang ada di desa. Revitalisasi ini juga membantu penenun untuk meningkatkan kualitas produk melalui pelatihan-pelatihan, serta membantu dalam promosi dan pemasaran produk. Menurutnya, penenun tenun ikat Dayak Sintang memiliki keunggulan karena mereka membuat motif tidak melihat contoh, tetapi membuat motif secara alami, misalnya setelah motif Sandung, penenun tahu motif berikutnya yang harus dibuat. Para penenun mengatakan orangtua mereka dulu menciptakan motif dari mimpi, inspirasi, dan nasihat. Ada orang yang memberikan nasihat dalam bentuk motif yang 
mempunyai makna baik, tetapi ada juga motif sakral yang tidak dapat dibuat oleh semua pengrajin, misalnya motif buaya, manusia dan semacam naga.

Narasumber lain yang menjual tenun ikat Dayak Sintang mulai berjualan sejak 2013 dan 2016. Narasumber yang memiliki toko sendiri sejak 2013 mengatakan kain tenun ikat Dayak Sintang pewarna kimia lebih banyak diminati pembeli lokal dan kain pewarna alam oleh orang luar. Menurutnya pembeli tidak mempermasalahkan mengenai jenis motif, tapi lebih memperhatikan warna dan kerapian penenunan, untuk motif yang penting bagi pembeli adalah bermotif Dayak. Mengenai sejarah tenun ikat, narasumber ini mengaku tidak terlalu memahami secara detail, ia hanya mengetahui bahwa kain tenun ikat Dayak Sintang itu per motif dan terdapat motif tua yang kainnya tidak boleh diperjualbelikan. Menurutnya, zaman dahulu hanya orang-orang tertentu yang memiliki kain tenun ikat karena tidak semua orang dapat membuatnya, dan apabila seseorang dapat menenun, nilai kasta di masyarakat lebih tinggi. Selain itu, proses penenunan zaman dahulu menggunakan benang yang diambil dari kulit buah nanas (seratnya) dan pewarnaannya menggunakan pewarna alam dari tumbuh-tumbuhan seperti buah kayu, akar kayu, dan daun-daunan. Sementara itu, narasumber yang menjaga galeri milik bibinya dengan sistem bagi hasil sejak 2016 mengatakan pembeli biasanya melihat kain tenun ikat dari kerapian penenunan, motif dan kecerahan warna. Banyak pembeli khususnya syal mencari kain tenun ikat berwarna merah karena identik dengan Dayak yang melambangkan keberanian. Menurutnya kain tenun ikat pewarna kimia lebih disukai masyarakat lokal dan kain pewarna alam biasanya diminati oleh pendatang seperti dari Jakarta. Narasumber ini mengaku tidak memahami tentang sejarah tenun ikat.

Narasumber terakhir adalah empat orang pemakai dan pengoleksi kain tenun ikat Dayak Sintang. Satu diantara tiga narasumber mengaku lebih senang dengan kain tenun ikat Dayak Sintang pewarna alam, lainnya pewarna kimia. Sedangkan untuk sejarah menenun mereka sama-sama tidak memahaminya, begitu pula dengan cerita motif dari kain yang mereka beli, dan hanya dua orang yang mengetahui beberapa nama motif dari kain yang mereka miliki. Seseorang menjelaskan mereka tidak mengerti cerita motif karena para penenun yang menjual kain kebanyakan tidak mengetahui cerita dari motif kain tenun ikat Dayak Sintang.

c) Interpretasi Objek

Interpretasi pada tenun ikat Dayak Sintang dibaca oleh pembaca tanda berdasarkan pada tanda-tanda yang ada dalam wujud fisik tenun ikat seperti motif kain, jenis kain, ukuran kain, pewarnaan kain dan bahan kain. Selain itu, latar belakang dan pengalaman (semiotic resources) dari masing-masing pembaca tanda juga memberikan pengaruh dalam proses interpretasi tersebut, sehingga memunculkan makna yang berbeda-beda diantara mereka.

Para pengurus adat dan temenggung merasa bangga memiliki tenun ikat Dayak Sintang, mereka melihat dan merasakan sendiri bagaimana tenun ikat memberikan semangat untuk pemakainya, memberikan penghasilan tambahan untuk para penenunnya, dan melambangkan rezeki yang besar atau kecil di dalam kehidupan mereka. Bagi para penenun, tenun ikat Dayak Sintang memberikan rasa bangga dan senang karena mereka dapat meneruskan tradisi dari nenek moyang sekaligus mendapatkan penghasilan tambahan untuk mencukupi kebutuhan rumah tangga dan pendidikan anak.

Narasumber yang terlibat dalam revitalisasi memaknai tenun ikat Dayak Sintang sebagai starting life karena pada saat itu ia baru mulai masuk dunia kerja, sedangkan lainnya merasa salut melihat kepandaian penenun membuat kain tenun ikat yang indah walaupun beberapa dari penenun tidak dapat membaca atau menulis. Sedangkan narasumber yang bekerja di koperasi JMM dengan latar belakang penenun merasa tenun ikat sangat bermakna bagi kehidupan karena melalui tenun ikat Dayak Sintang budaya 
berkembang dan ekonomi menjadi meningkat. Bagi narasumber yang terlibat langsung dalam revitalisasi, tenun ikat adalah budaya yang betul-betul luar biasa dan merupakan identitas kebudayaan masyarakat Dayak. Ia yang bukan dari suku Dayak mempelajari bahwa suku daerah lain juga memiliki kebudayaan yang luar biasa, yang harus dilestarikan, dihargai, dan dipromosikan.

Penjual tenun ikat Dayak Sintang memaknai tenun ikat sebagai aset budaya atau aset masyarakat setempat, tenun ikat memiliki nilai dari segi ekonomi, budaya, dan adat. Lainnya merasa bersemangat karena melalui tenun ikat Dayak Sintang budaya dapat diangkat dan dikenal banyak orang. Sedangkan makna bagi keempat pemakai dan pengoleksi, kain tenun ikat Dayak Sintang adalah identitas subsuku dan sebagai cara mencintai budaya sendiri.

d) Pertukaran Tanda dan Makna

Para pengurus adat dan temenggung mempertukarkan tanda dan makna dari kain tenun ikat Dayak Sintang melalui penggunaan kain dalam prosesi adat seperti gawai adat, Musyawarah Adat (MUSDAT), Rapat Koordinasi (RAKOR) adat, adat memandikan anak ke sungai, adat mengambil semengat padi, dan menyambut tamu. Hal yang hampir serupa juga terjadi pada para penenun, mereka mempertukarkan tanda dan makna melalui pemakaian tenun ikat Dayak Sintang dalam proses penenunan seperti peminyakan (ngaos) dan pewarnaan kain dengan pewarna alam, adat tutup tahun, menikah adat, adat memandikan anak ke sungai, adat mengambil semengat padi, adat mengasah gigi anak, adat saat nugal di ladang apabila menemukan lebah saat menebas di ladang, menyambut tamu, ke gereja dan mengikuti pameran atau pelatihan. Sedangkan para narasumber lain umumnya mempertukarkan tanda dan makna tenun ikat Dayak Sintang dengan menggunakan tenun ikat sebagai pakaian dan pemanis penampilan (aksesoris) pada acara kantor, kegiatan keagamaan, jalanjalan, resepsi pernikahan, wisuda anak, dan gawai Dayak. Selain itu, tenun ikat Dayak Sintang juga dipakai sebagai interior rumah. e) Lingkungan Sosial

Lingkungan sosial dalam penelitian ini dibagi menjadi empat yakni lingkup desa, kabupaten, nasional dan internasional. Dalam lingkup desa, tenun ikat Dayak Sintang umumnya dipakai dalam proses penenunan dan kegiatan adat istiadat. Dalam lingkup kabupaten, tenun ikat Dayak Sintang umumnya digunakan dalam kegiatan adat tingkat kabupaten, kegiataan keagamaan, resepsi pernikahan, pameran, demo menenun, interior rumah dan pemanis penampilan misalnya aksesoris tas, gelang tangan, ikat kepala, tas tangan, dompet, sepatu atau sendal. Dalam lingkup nasional dan internasional, tenun ikat Dayak Sintang dipakai oleh pemerintah Kabupaten Sintang sebagai artefak budaya, identitas daerah, komoditas ekonomi, potensi wisata dan investasi. Hal tersebut tampak dari peran beberapa dinas yang saling terkait dan bersinergi mengembangkan dan melestarikan tenun ikat Dayak Sintang seperti Dinas Pendidikan dan Kebudayaan, Dinas Perindustrian, Perdagangan, Koperasi dan UKM (DISPERINDAGKOP dan UKM), Dinas Pariwisata, dan Dinas Penanaman Modal dan Pelayanan Terpadu Satu Pintu (DPMPTSP).

Peran Dinas Pendidikan dan Kebudayaan lebih pada memproteksi kebudayaan, dalam konteks ini tenun ikat Dayak Sintang. Hal-hal yang dilakukan antara lain membuat ruang pameran tenun ikat Dayak Sintang di museum Kapuas Raya, sehingga para pengunjung dapat mengetahui sejarah tenun ikat Dayak Sintang mulai dari proses pembuatannya. Ada pula festival tenun ikat yang diadakan setiap tahun sebagai ajang berlomba, bersaing sehat dan mengekspresikan kemampuan menenun bagi para penenun tenun ikat Dayak Sintang. Festival ini membantu para penenun untuk tetap bersemangat menenun karena hal tersebut merupakan tradisi dari para leluhurnya. 
Selain itu, Dinas Pendidikan dan Kebudayaan juga mengadakan pameran dan workshop tenun ikat Dayak Sintang sesuai permintaan penyelenggara misalnya di Eropa dan Amerika seperti Leiden, Oakland dan sebagainya. Pada pameran biasanya ditayangkan video proses pembuatan tenun ikat Dayak Sintang, sedangkan dalam workshop diajarkan bagaimana menenun dari proses memintal benang, mengikat, mencelup atau memberi warna sampai pemanfaatan bahan tenun ikat yang dapat digunakan sebagai bahan pakaian. Pameran dan workshop tersebut melibatkan penenun secara langsung.

Peran DISPERINDAGKOP dan UKM lebih banyak pada pembinaan para penenun dan mempromosikan tenun ikat Dayak Sintang keluar daerah Sintang. Bentuk pembinaan yang dilakukan umumnya berupa pelatihan untuk meningkatkan standar kualitas tenunan, mulai dari ukuran, motif dan pewarnaan. Melalui DISPERINDAGKOP dan UKM pula para penenun mulai mengenal pewarnaan kimia dan membuat jenis kain seperti syal, taplak meja dan sebagainya. Selain itu, DISPERINDAGKOP dan UKM juga bekerja sama dengan PEMDA, BUMD dan BUMN untuk membantu para penenun, misalnya dalam penyediaan bahan baku dan memberikan sosialisasi untuk menjaga mutu, serta pembuatan buku mengenai tenun ikat Dayak Sintang kerja sama Dekranasda kabupaten dan pusat serta Yayasan Kobus. Dalam hal promosi ke luar Kalimantan Barat, DISPERINDAGKOP dan UKM mengikuti pameran-pameran seperti INACRAFT dan pameran dari Dekranasda.

Peran Dinas Pariwisata lebih banyak pada promosi kemanfaatan produk tenun ikat Dayak Sintang sebagai produk atau kerajianan lokal yang dapat menjadi cendera mata bagi para turis. Promosi yang dilakukan Dinas Pariwisata biasanya melalui pameran dan festival, misalnya pameran di Batam, festival di Yogyakarta dan pembukaan stand di Asian Games
Palembang 2018. Dalam mengikuti festival biasanya Dinas Pariwisata membawa penenun yang langsung mempraktikkan proses menenun sehingga pengunjung yang datang ke stand dapat langsung melihat proses menenun dan bertanya seputar tenun ikat Dayak Sintang kepada penenun. Sedangkan pada pameran yang tidak melibatkan penenun, Dinas Pariwisata menggunakan kain tenun ikat Dayak Sintang sebagai backdrop, taplak meja, dan pakaian yang dipakai penjaga stand. Kebanyakan pengunjung yang membeli tenun ikat Dayak Sintang dalam festival dan pameran melihat kualitas kain dan motif kain yang bagus, tetapi mereka tidak terlalu mempermasalahkan cerita pada motif.

Peran lainnya dilakukan DPMPTSP yang mempromosikan tenun ikat Dayak Sintang kepada para investor agar para investor dapat menjadi mitra bagi para penenun dalam mengembangkan pangsa pasar tenun ikat Dayak Sintang. Misalnya, dalam Festival Investasi Bukit Kelam (Festinvest) tahun 2018, kain tenun ikat Dayak Sintang dipakai sebagai interior di tempat pelaksanaan business meeting, sehingga para investor dapat melihat secara langsung hasil kain tenun ikat Dayak Sintang yang dibuat para penenun. Hal ini dilakukan karena Desa Ensaid Panjang yang merupakan sentra tenun ikat Dayak Sintang menjadi bagian dalam wilayah Kecamatan Kelam di mana festival ini berlangsung.

Selain peran pemerintah dalam lingkup nasional dan internasional, adapula peran swasta dalam mempromosikan tenun ikat Dayak Sintang seperti Koperasi JMM dan Galeri Kain Pantang Sintang, Kalbar. Menurut karyawan Koperasi JMM biasanya orangorang yang berkunjung ke galeri adalah tamu-tamu pihak swasta dan pemerintah yang berasal dari Pontianak, Jakarta, Serawak Malaysia, Australia, Belanda dan negara lainnya. Biasanya mereka membeli tenun ikat sebagai cendera mata khas 
Sintang. Kebanyakan pengunjung tertarik membeli kain tenun ikat Dayak Sintang karena motif dan cerita motifnya, dan mereka lebih menyukai kain dengan pewarna alam. Sedangkan menurut pemilik Galeri Kain Pantang Sintang, Kalbar yang menjual kain tenun ikat secara online, pembeli kain tenun ikat Dayak Sintang kebanyakan berasal dari Jawa Timur, Yogjakarta, Jakarta, dan Bali. Beberapa dari pelanggannya merupakan desainer yang memiliki jaringan ke Australia dan Belanda sehingga kain tenun ikat Dayak Sintang dibawa sebagai fashion ke mancanegara. Kebanyakan pembeli adalah pencinta budaya atau pencinta tenun dan mereka tertarik membeli karena kualitas kain, motif dan cerita motif, limited edition (untuk ukuran kumbu dan kebat hanya dua lembar sekali tenun, kainkain yang ditenun tidak akan ada yang sama karena tidak ada standar kain dan standar pewarnaan) dan cerita kehidupan para perempuan Dayak (penenun).

f) Dimensi dari Analisis Semiotika Sosial

\section{Discourse}

Discourse (wacana) adalah kunci untuk mempelajari bagaimana sumber daya semiotika digunakan untuk membangun representasi dari apa yang sedang terjadi di dunia (Leeuwen, 2005, p.91).

Dalam penjabaran di latar belakang, kain tenun ikat yang ditenun oleh manusia yang pengetahuan awalnya didapatkan dari manusia setengah dewa dan binatang (ringkat/ingkat) mewakili kehidupan manusia yang harmonis dengan alam, binatang dan kehidupan lain di dalamnya. Pada saat itu kain tenun ikat berfungsi sebagai pelindung tubuh manusia dan kebutuhan adat seperti menyambut kepala hasil ngayau. Untuk prosesi adat ini dibutuhkan kain tenun ikat bermotif khusus seperti Merinjan dan Ruit. Motifmotif yang terkandung di dalam kain tenun ikat menjadi sarana bagi para leluhur untuk menyampaikan pesan, nasihat atau petuah, dan kebudayaan Dayak kepada anak cucu mereka. Semua itu tampak dari cerita dan arti motif yang sangat erat hubungannya dengan kehidupan orang Dayak sejak zaman dahulu.

Selain itu, proses yang rumit dan panjang untuk membuat kain tenun ikat juga mewakili kesabaran, ketekunan, keberanian dan semangat pantang menyerah para perempuan Dayak. Peminyakan benang dan pewarnaan kain tenun ikat yang menggunakan bahanbahan dari tumbuh-tumbuhan dan hewani menjadi simbol kebijaksanaan dalam memanfaatkan sumber daya di sekitar manusia. Fungsi lain kain tenun ikat yang dipaparkan para narasumber untuk prosesi adat memandikan anak ke sungai, mengasah gigi anak (saat anak memasuki usia remaja), pernikahan, nugal (menanam padi), gawai atau pesta panen atau tutup tahun, mengambil semengat padi, menyambut tamu, dan kematian melambangkan bahwa tenun ikat memiliki peranan yang sangat penting dalam kehidupan orang Dayak.

Ketika orang Dayak sudah mendapat pengaruh dari luar dan mengenal pakaian siap pakai dalam uraian di latar belakang, manusia memandang tenun ikat sebagai lambang ketertinggalan atau keterbelakangan, orang-orang yang masih memakai kain tenun ikat dianggap primitif oleh orang-orang di sekitarnya. Di sinilah terjadi pergeseran makna karena pengaruh dari luar yang membentuk pemahaman baru terhadap kain tenun ikat. Bertahuntahun kemudian, muncullah pastor Jacques Maessen, SMM yang memiliki kecintaan terhadap seni dan budaya, ia menemukan bahwa tenun ikat lebih dari pakaian dan merupakan sesuatu yang sangat penting, di mana kebudayaan Dayak tertuang di dalam motif-motif kain tenun ikat untuk disampaikan kepada anak cucu mereka. Hal ini memunculkan inisiatif untuk kembali melestarikan tradisi menenun tenun ikat. Dalam program pelestarian yang dikenal dengan nama "Restorasi Tenun Ikat Dayak" muncul dua pandangan baru mengenai tenun ikat yaitu sebagai artefak budaya yang perlu dilestarikan dan kain yang memiliki nilai ekonomis.

Lambat laun, seperti yang dipaparkan dalam lingkungan sosial, kain tenun ikat 
Dayak Sintang mulai dikenal masyarakat lokal, nasional dan internasional melalui peran dari pemerintah dan pihak swasta. Peran pemerintah dilakukan melalui Dinas Pendidikan dan Kebudayaan, DISPERINDAGKOP dan UKM, Dinas Pariwisata, dan DPMPTSP. Dinas Pendidikan dan Kebudayaan mewakili makna tenun ikat Dayak Sintang sebagai artefak budaya. Makna ini dipertukarkan melalui ruang pemeran di museum Kapuas Raya, festival tenun ikat, pameran dan workshop di luar negeri, kepada penenun, masyarakat Sintang dan orang-orang di luar Sintang sehingga orang-orang dapat mengenal dan memahami tentang tenun ikat Dayak Sintang.

DISPERINDAGKOP dan UKM mewakili makna tenun ikat Dayak Sintang sebagai komoditas ekonomi. Makna ini dipertukarkan kepada penenun melalui pelatihan standarisasi kualitas produk tenun ikat Dayak Sintang dan kepada pihak luar melalui pemeran INACRAFT dan pameran dari Dekranasda yang memperlihatkan kualitas tenun ikat Dayak Sintang yang tidak kalah dengan kain tenun ikat dari daerah lain. Selain itu, makna tenun ikat Dayak Sintang sebagai komoditas ekonomi juga diwakili oleh pihak swasta seperti Koperasi JMM dan Galeri Kain Pantang Sintang, Kalbar. Makna ini dipertukarkan dengan menjelaskan nama dan cerita motif pada kain tenun ikat Dayak Sintang dan kehidupan para penenun, sehingga menarik perhatian pembeli untuk memiliki kain tenun ikat Dayak Sintang dan terjadi transaksi jual-beli.

Dinas Pariwisata mewakili makna tenun ikat Dayak Sintang sebagai identitas sosial masyarakat setempat. Makna ini dipertukarkan dalam festival dan pameran yang memperlihatkan tenun ikat Dayak Sintang sebagai kerajinan khas masyarakat setempat, baik kepada masyarakat lokal maupun masyarakat di luar Sintang. Sedangkan, DPMPTSP mewakili makna tenun ikat Dayak Sintang sebagai potensi wisata dan investasi. Makna dipertukarkan melalui display kain tenun ikat Dayak Sintang dalam interior tempat business meeting para investor Festinvest. Display ini secara otomatis menarik perhatian para investor terhadap tenun ikat Dayak Sintang.

\section{Genre}

Konsep genre adalah kunci untuk mempelajari bagaimana sumber daya semiotika digunakan untuk memerankan interaksi komunikatif - interaksi yang melibatkan representasi (Leeuwen, 2005, p.91). Genre pada tenun ikat Dayak Sintang dibagi dalam geografis yakni desa, kabupaten, nasional dan internasional.

Dalam lingkup desa seperti yang dipaparkan pada lingkungan sosial, genre yang terbentuk adalah budaya. Tenun ikat Dayak Sintang dipandang sebagai budaya dari leluhur yang digunakan untuk menyampaikan pesan, nasihat atau petuah dan kebudayaan Dayak kepada anak cucu mereka. Hal ini tampak pada nama dan cerita motif yang tertuang dalam tiap kain tenun ikat Dayak Sintang. Kisah-kisah tersebut sangat erat kaitannya dengan kehidupan orang Dayak zaman dahulu dan dapat direfleksikan menjadi pesan yang bermanfaat di masa sekarang. Selain itu, tenun ikat Dayak Sintang dipandang pula sebagai bagian dari ritual masyarakat setempat dan bersifat sakral. Hal ini tampak dari penggunaan kain tenun ikat Dayak Sintang dengan motif-motif tertentu untuk ritual tertentu, dan perlakukan terhadap kain tenun ikat Dayak Sintang seperti kain yang tidak boleh dipotong sembarang untuk motif manusia dan Rabing. Pertukaran tanda dan makna tenun ikat Dayak Sintang sebagai budaya ini dilakukan dalam proses ngaos, pewarnaan kain, dan acara adat istiadat yang berlangsung di desa setempat dan bersifat lokal.

Dalam lingkup kabupaten, genre yang terbentuk adalah identitas sosial. Tenun ikat Dayak Sintang dipandang sebagai identitas sosial penduduk setempat baik oleh orang Dayak maupun orang-orang di luar suku Dayak. Pembentukan genre ini dipengaruhi pula oleh peran pemerintah melalui Dinas Pariwisata, misalnya dalam pameran dan festival. Tenun ikat Dayak Sintang sebagai identitas sosial terlihat dari penggunaan tenun ikat Dayak Sintang 
dalam kegiatan masyarakat setempat mulai dari kegiatan pribadi sampai kegiatan resmi yang mewajibkan penggunaan kain tenun ikat Dayak Sintang. Pertukaran tanda dan makna ini dilakukan dalam penyambutan tamu, pemberian cendera mata, penggunaan kain tenun ikat Dayak sebagai bahan pakaian, aksesoris tambahan untuk penampilan dan interior rumah.

Dalam lingkup nasional, genre yang terbentuk adalah aktualisasi diri. Tenun ikat Dayak Sintang dipandang sebagai bagian dari warisan budaya nasional dan digunakan sebagai aktualisasi diri dalam mencintai warisan budaya sendiri. Pembentukan genre ini dipengaruhi pula peran Dinas Pendidikan dan Kebudayaan dan DISPERINDAGKOP dan UKM, namun yang lebih dominan adalah DISPERINDAGKOP dan UKM. Pertukaran tanda dan makna tenun ikat Dayak Sintang sebagai bagian dari aktualisasi diri terlihat dari penggunaan tenun ikat Dayak Sintang sebagai fashion oleh masyarakat nasional.

Dalam lingkup internasional, genre yang terbentuk adalah warisan budaya. Tenun ikat Dayak Sintang dipadang sebagai warisan budaya suatu bangsa (Indonesia) yang menarik untuk dikaji lebih dalam melalui studi atau penelitian. Pembentukan genre ini dipengaruhi pula peran Dinas Pendidikan dan Kebudayaan yang biasanya melakukan pameran dan workshop tenun ikat Dayak Sintang ke luar negeri. Pertukaran tanda dan makna tenun ikat Dayak Sintang sebagai warisan budaya terlihat dari ketertarikan orang luar negeri untuk meneliti dan memahami tenun ikat Dayak Sintang secara mendalam.

\section{Style}

Konsep style adalah kunci untuk mempelajari bagaimana orang menggunakan sumber daya semiotika untuk 'menunjukkan' genre, dan untuk mengekspresikan identitas dan nilai mereka dalam melakukannya (Leeuwen, 2005, p.91). Style pada tenun ikat Dayak Sintang dibagi dalam lingkup desa, kabupaten, nasional dan internasional.
Dalam lingkup desa, masyarakat menggunakan tenun ikat Dayak Sintang dalam proses penenunan dan ritual adat seperti proses ngaos, pewarnaan kain, pernikahan adat, gawai atau adat tutup tahun, adat mengambil semengat padi, adat memandikan anak ke sungai, adat mengasah gigi anak, adat saat nugal di ladang, rapat adat, dan penyambutan tamu yang berkunjung ke kampung. Penduduk desa yang merupakan masyarakat adat ini masih menaati peraturan adat istiadat yang berlaku di tempat mereka tinggal, terutama masyarakat yang tinggal di rumah betang (Desa Ensaid Pajang). Segala sesuatu yang berurusan dengan adat harus didiskusikan dengan temenggung atau pengurus adat setempat. Pelanggaran terhadap adat istiadat oleh masyarakat akan berujung pada pemberlakuan hukum adat. Kepatuhan masyarakat terhadap adat berlaku pula dalam penggunaan kain tenun ikat Dayak Sintang ini, sehingga apabila mereka tidak memiliki kain tenun ikat Dayak Sintang mereka menyewa kain tersebut dari penduduk setempat.

Dalam lingkup kabupaten, masyarakat menggunakan tenun ikat Dayak Sintang dalam kegiatan resmi dan harian mereka seperti gawai adat, MUSDAT, RAKOR adat, resepsi pernikahan, acara gereja atau ke gereja, majelis taklim, pameran, demo menenun, penyambutan tamu, sebagai bahan dekorasi rumah seperti taplak meja, sarung bantal, hiasan dinding, sebagai pemanis penampilan misalnya aksesoris tas, gelang tangan, ikat kepala, tas tangan, dompet, sepatu atau sendal. Penduduk Kabupaten Sintang terutama di perkotaan tergolong mudah terbuka terhadap perubahaan. Hal ini tampak saat tenun ikat Dayak Sintang mulai dikembangkan menjadi identitas sosial penduduk setempat, respon positif bermunculan dari penduduk dan mereka ikut memakai tenun ikat Dayak Sintang sebagai bagian dari identitas diri mereka.

Dalam lingkup nasional dan internasional, pemerintah dan pihak swasta menggunakan tenun ikat Dayak Sintang dalam pameran, workshop, acara resmi dan fashion show. Penduduk nasional (Indonesia) tentu sangat terbuka terhadap 
trend-trend yang sedang berkembang di sekitar mereka. Hal ini membuat mereka sangat mudah menerima tenun ikat Dayak Sintang menjadi lifestyle mereka terutama dalam mengaktualisasi diri mencintai warisan budaya Indonesia. Hal yang sedikit berbeda terjadi pada penduduk internasional, kebanyakan mereka hidup secara modern dan tidak bersentuhan langsung dengan budaya sehingga mereka lebih senang memandang tenun ikat Dayak Sintang sebagai warisan budaya suatu negara yang menarik untuk diteliti dan dipahami lebih dalam. Hal ini dapat terlihat ketika mereka mengundang pihak pemerintah untuk mengadakan pameran dan workshop mengenai tenun ikat Dayak Sintang.

\section{Modality}

Modality (modalitas) adalah kunci untuk mempelajari bagaimana orang menggunakan sumber daya semiotika untuk menciptakan kebenaran atau nilainilai realitas dari representasi mereka, untuk berkomunikasi, untuk misalnya, apakah itu harus diambil sebagai fakta atau fiksi, kebenaran atau dugaan yang sudah terbukti, dll (Leeuwen, 2005, p.91). Modality pada tenun ikat Dayak Sintang dibagi dalam lingkup desa, kabupaten, nasional dan internasional.

Dalam lingkup desa, penduduk menganggap tenun ikat Dayak Sintang sebagai bagian dari budaya (adat istiadat dan ritual) dan komoditas ekonomi. Modalitas yang terbentuk dalam lingkup desa ini tinggi. Masyarakat Dayak memang terkenal kaya akan adat istiadat dan ritual, hal tersebut dapat dilihat dalam kehidupan sehari-hari mereka terutama dalam proses penenunan di mana terdapat pantangan dan ritual yang harus mereka jalankan dan patuhi. Misalnya pantangan tidak boleh menenun di malam hari karena bunyi alat tenun akan terdengar oleh orang-orang di Sebayan, tidak boleh melakukan pencelupan apabila sedang datang bulan, tidak boleh menenun apabila ada orang yang meninggal di kampung tersebut, membuat sesajen sebelum dan setelah menyelesaikan proses penenunan, dan sebagainya.
Selain itu, pekerjaan penduduk desa yang mayoritas sebagai petani karet dan peladang sangat bergantung pada penghasilan dari karet dan padi yang mereka tanam. Untuk memenuhi kebutuhan sehari-hari mereka menyisihkan pendapatan dari menoreh karet, dan apabila terjadi penurunan harga karet maka akan sangat berdampak bagi kehidupan mereka. Kehadiran tenun ikat Dayak Sintang dapat dikatakan sebagai jawaban dari kegelisahan masyarakat setempat, tenun ikat Dayak Sintang menjadi alternatif pendapatan bagi keluarga sehingga mereka dapat mencukupi kebutuhan sehari-hari dan menyekolahkan anak-anak hingga ke perguruan tinggi.

Dalam lingkup kabupaten, penduduk menganggap tenun ikat Dayak Sintang sebagai identitas sosial. Modalitas ini tinggi karena didukung pula oleh pemerintah melalui Dinas Pariwisata. Selain itu, penduduk Kabupaten Sintang yang mayoritas merupakan suku Dayak dan Melayu telah berkontribusi dalam pembentukan identitas sosial ini dengan ikut membeli, memakai, mengoleksi dan mempromosi kain tenun ikat Dayak Sintang dalam kehidupan sehari-hari mereka.

Dalam lingkup nasional, penduduk menganggap tenun ikat Dayak Sintang sebagai bagian dari aktualisasi diri. Modalitas ini rata-rata karena dapat bersifat sementara. Kecintaan masyarakat Indonesia terutama dalam dunia fashion membuat mereka ingin ikut berpartisipasi dalam mendukung tenun ikat Dayak Sintang sebagai warisan budaya yang dapat digunakan untuk mempercantik penampilan. Namun, hal ini dapat berubah ketika mereka mendapatkan pengaruh baru dalam dunia fashion tersebut, misalnya trend yang berubah.

Sedangkan, dalam lingkup internasional, penduduk menganggap tenun ikat Dayak Sintang sebagai warisan budaya yang menarik untuk diteliti lebih dalam. Modalitas ini tinggi karena mulai bermunculan penelitian mengenai tenun ikat Dayak Sintang terutama di negara seperti Belanda. Hal ini didukung pula 
oleh peran pemerintah melalui Dinas Pendidikan dan Kebudayaan dan pastor Jacques Maessen, SMM yang mempromosikan tenun ikat Dayak Sintang kepada sahabat, keluarga dan kenalannya di Belanda dan negara lain.

Dalam analisis makna tenun ikat Dayak Sintang ini ditemukan bahwa pergeseran makna terjadi ketika ada pengaruh dari luar yang mengubah pandangan orang Dayak mengenai tenun ikat Dayak Sintang. Makna yang awalnya sebagai media penyampaian pesan, nasihat dan kebudayaan Dayak bergeser menjadi artefak budaya, identitas daerah, komoditas ekonomi dan potensi wisata dan investasi. Selain itu, ditemukan pula peran pemerintah dan pihak swasta dalam pembentukan makna baru tersebut. Peran ini mempercepat pembentukan dan perluasan makna kepada masyarakat luas. Ada pula temuan bahwa dalam tiap lingkup geografis yang berbeda makna yang terbentuk berbeda. Hal ini dipengaruhi oleh latarbelakang dan kepentingan dari masing-masing pihak yang berada dalam lingkup tersebut misalnya lingkup desa, kabupaten, nasional dan internasional. 


\section{SIMPULAN}

Tenun ikat Dayak Sintang merupakan salah satu kerajinan khas suku Dayak di Kabupaten Sintang yang tengah populer dan digemari masyarakat setempat dan telah dikenal hingga ke mancanegara terutama Belanda. Hal ini mendasari peneliti untuk mengangkat tenun ikat Dayak Sintang sebagai objek penelitian. Berdasarkan analisis semiotika sosial yang dilakukan menggunakan empat dimensi yakni discourse, genre, style, dan modality, maka dapat disimpulkan bahwa makna tenun ikat Dayak Sintang saat ini adalah sebagai artefak budaya, identitas daerah, komoditas ekonomi serta potensi wisata dan investasi. Makna tersebut muncul karena dipengaruhi oleh pihak-pihak yang memiliki peran dominan dalam mengembangkan dan melestarikan tenun ikat Dayak Sintang seperti pihak pemerintah dan swasta. Selain itu, pertukaran tanda dan makna tenun ikat Dayak Sintang dilakukan dalam empat lingkup geografis seperti lingkup desa, kabupaten, nasional dan internasional. Dalam lingkup desa pertukaran dilakukan melalui budaya, dalam lingkup kabupaten melalui identitas sosial, dalam lingkup nasional melalui aktualisasi diri dan dalam lingkup internasional melalui warisan budaya.

Berdasarkan penelitian ini diharapkan ke depan dapat dilakukan penelitian lain mengenai artefak budaya yang dihubungkan dengan Marketing Communication menggunakan teori semiotika sosial Theo Van Leeuwen terutama pada cakupan wilayah pertukaran tanda dan makna yang lebih luas dimulai dari desa, kabupaten, nasional dan internasional.

\section{DAFTAR PUSTAKA}

Creswell, J. W. 2010. Research design: pendekatan kualitatif, kuantitatif, dan mixed (Translated by Fawaid, A, Trans). Celeban Timur, Yogyakarta: Pustaka Pelajar.

Denzin, N. K., \& Lincoln, Y. S. 2009. Handbook of qualitative research. (Translated by Dariyanto, Fata, Abi, \&
Rinaldi). Celeban Timur, Yogyakarta: Pustaka Pelajar.

Faiz. 2014, April 25. Tenun ikat Dayak Sintang dipromosikan di pameran kerajinan internasional. Diperoleh pada March 2, 2019, dari https://kalbar.antaranews.com/berita/3 22219/tenun-ikat-dayak-sintangdipromosikan-di-pameran-kerajinaninternasional

Halliday, M.A.K. 1978. Language as Social Semiotic. London: Arnold.

Hiasintus. 2017, August 23. Penuhi undangan, Kabupaten Sintang adakan pameran dan workshop tenun ikat Sintang di Belanda. Diperoleh pada March 2, 2019, dari https://kebudayaan.kemdikbud.go.id/b pnbkalbar/penuhi-undangankabupaten-sintang-adakan-pamerandan-workshop-tenun-ikat-sintang-dibelanda/

Kemdikbud. (n.d.). Warisan Budaya Tak Benda (WBTB) Indonesia. Diperoleh pada May 22, 2018, dari http://kwriu.kemdikbud.go.id/infobudaya-indonesia/warisan-budaya-takbenda-indonesia/

Koperasi JMM. 2017. Data Pengrajin [file excel]. Dikirim dengan WhatsApp.

Leeuwen, T. Van. 2005. Introducing social semiotics. Oxon: Routledge.

Oliv, O. 2017. Jefray Edward Resmi Pimpin $D A D$ Sintang , sintang.go.id. Diperoleh pada February 16, 2019, dari http://www.sintang.go.id/news/index/1 378

PRCF Indonesia. 2008, April 27. Kain tenun ikat Dayak [Blog post]. Diperoleh pada May 22, 2018, dari http://tenunikat.blogspot.com/2008/04/ kain-tenun-ikat-dayak.html

Saussure, F. De. 1974 [1916]. Course in General Linguistics. London: Peter Owen.

Wempi, J. A. 2018. Social semiotics: Kajian atas buku "Introducing social semiotics" Theo Van Leeuwen [Bahan 
kuliah]. Jakarta, Indonesia : London School of Public Relations-Jakarta.

Yayasan Kobus, Koperasi Jasa Menenun Mandiri, \& Ford Foundation. 2011. Sertifikat kain: Cerita dan motif kain. Sintang, Indonesia : Yayasan Kobus, Koperasi Jasa Menenun Mandiri, \& Ford Foundation. 